\title{
Mesenchymal Stem Cells: Sources, Clinical Applications and Outcomes for Common Musculoskeletal Conditions
}

Steven Boyton, MS, ATC, OTC; Lindsey Clemensen, MEd, ATC, OTC

Flagstaff Bone and Joint, Flagstaff, AZ

\section{Full Citation}

Boyton S, Clemenson L. Mesenchymal stem cells: sources, clinical applications and outcomes for common musculoskeletal conditions. Clin Pract Athl Train. 2020;3(1):4-5.

https://doi.org/10.31622/2020/0003.2.

Presented at the $3^{\text {rd }}$ Annual Athletic Trainers in the Physician Practice Society Meeting and Conference, Columbia South Carolina. February 28-29, 2020

\section{ABSTRACT}

Background: The clinical use of Mesenchymal Stems Cells (MSC) in musculoskeletal medicine has become increasingly recognized in the medical field as a promising treatment modality. MSCs have been defined as spindle shaped cells that are capable of rapid proliferation and selfrenewal contained within several tissues including bone marrow, synovial and adipose tissue, blood and periosteum. MSCs are currently being used in clinical trials for musculoskeletal purposes including the enhancement of tissue regeneration, bone and cartilage defects and tissue repair. Currently a variety of stem cell products, methods and applications are being used which can provide many misconceptions for the most appropriate use of this modality in orthopedics. The decision for the functionally relevant cell type is important to understand for providers to have the most effective outcomes.

Methods: Common methods of evaluating the effect of MSCs in orthopedics include patient rated outcomes, advanced imaging comparisons, arthroscopic evaluation after treatment and gene expression analysis. A comprehensive literature review was conducted to evaluate the most highlevel evidence available for MSC's being utilized in orthopedics. This is important to understand for clinicians to make informed decisions for the most appropriate clinical applications of MSCs.

Conclusion: Despite the many positive outcomes being demonstrated with MSC therapies, in the literature for various orthopedic conditions, the magnitude of these positive effects have been diverse due to the lack of standardization of the MSC cell product. Further research is required to provide an insight into long term outcomes relative to other treatment modalities. Additionally, research must also determine if the use of MSC therapies can become a viable treatment option for musculoskeletal pathologies in orthopedic practices to use with standardized products and processing methods.

Clinical Bottom Line: The literature for MSC therapy outcomes that have been observed in clinical trials have been lacking standardization with regards to how stem cells are being obtained, processed and utilized for musculoskeletal conditions. Further research is required to provide an insight into long term outcomes relative to other treatment modalities. Additionally, research must also determine if the use of MSC therapies can become a viable treatment option for musculoskeletal pathologies in orthopedic practices to use with standardized products and processing methods.

Correspondence

Steven Boyton, 2292 Hano Trail, Flagstaff, AZ 86005.

E-mail:sboyton@flagstaffboneandioint.com

\section{REFERENCES}

1. Kim JD, Lee GW, Jung GH, Kim CK, Kim T, Park JH, Cha SS, You YB. Clinical outcome of autologous bone marrow aspirates concentrate (BMAC) injection in degenerative arthritis of the knee. Eur $J$ 
Orthop Surg Traumatol.

2014;24(8):1505-1511.

https://doi.org/10.1007/s00590-013-

1393-9.

2. Koh YG, Jo SB, Kwon OR, Suh DS, Lee SW, Park SW, Choi YJ. Mesenchymal stem cell injections improve symptoms of knee osteoarthritis. Arthroscopy.

2013;29(4):748-755.

https://doi.org/10.1016/i.arthro.2012. 11.017 .

3. Awad ME, Hussein KA, Helwa I, Abdelsamid ME, Aguilar-Pere A, Moshen I, Hunter $M$, et al. Meta-analysis and evidence base for the efficacy of autologous bone marrow mesenchymal stem cells in knee cartilage repair: Methodological guidelines and quality assessment. Stem Cells Int. 2019:

3826054.

https://doi.org/10.1155/2019/38260 54.

4. Lopa S, Colombini A, Moretti M, de Girolamo L. Injective mesenchymal stem cell-based treatments for knee osteoarthritis: from mechanisms of action to current clinical evidences. Knee Surg Sports Traumatol Arthrosc. 2019;27(6), 2003-2020.

https://doi.org/10.1007/s00167-0185118-9.

5. Chahla J, Piuzzi NS, Mitchell JJ, Dean CS, Pascual-Garrido C, LaPrade RF, Muschler GF. Intra-articular cellular therapy for osteoarthritis and focal cartilage defects of the knee: a systematic review of the literature and study quality analysis. J Bone Joint Surg Am. 2016;98(18):1511-1521. https://doi.org/10.2106/JBJS.15.0149 5.

6. Harrell CR, Markovic BS, Fellabaum C, Arsenijevic A, Volarevic V. Mesenchymal stem cell-based therapy of osteoarthritis: Current knowledge and future perspectives. Biomed
Pharmacother. 2019;109:2318-2326. https://doi.org/10.1016/i.biopha.2018 .11 .099 .

7. Jones IA, Chen X, Evseenko D, Vangsness Jr CT. Nomenclature inconsistency and selective outcome reporting hinder understanding of stem cell therapy for the knee. J Bone Joint Surg Am. 2019;101(2):186-195. https://doi.org/10.2106/JBJS.17.0147 4 